\title{
Análise físico-química e percepção ambiental do córrego Engole Cobra no município de Cuiabá-MT
}

\author{
Cecília Cavalcante Silva Marsaro '; Carla Maria Abido Valentini '; Rozilaine Aparecida Pelegrine \\ Gomes de Faria "; Alexandre Silva Abido ${ }^{2}$ \\ $\triangle$ ceciliamarsaro@hotmail.com \\ 1. Instituto Federal de Educação, Ciência e Tecnologia de Mato Grosso (IFMT) - Campus Cuiabá - Bela Vista, Av. \\ Juliano Costa Marques, s/n, Cuiabá, Brasil. \\ 2. Universidade Federal de Mato Grosso (UFMT) - Campus Cuiabá, Avenida Fernando Corrêa da Costa, s/n, Cuiabá, \\ Brasil
}

Histórico do Artigo:

Recebido: 20 de outubro de 2016

Aceito: 28 de junho de 2017

Publicado: 18 de julho de 2017

Resumo: 0 município de Cuiabá pode ser considerado privilegiado do ponto de vista de recursos hídricos. Porém, a acelerada urbanização e o crescimento econômico da capital, a partir dos anos 70, afetaram a qualidade desses recursos, especialmente de seus córregos urbanos. Nesse contexto está inserido o córrego Engole Cobra, um dos mais de 30 córregos urbanos de Cuiabá. 0 objetivo deste trabalho foi analisar a qualidade da água do córrego Engole Cobra e avaliar o nível de percepção ambiental dos moradores do seu entorno. Para a avaliação da percepção, foi aplicado um questionário semiestruturado de modo a registrar histórica e socialmente a importância do córrego para a vida dessas pessoas. 0s parâmetros físico-químicos avaliados para a qualidade da água foram $\mathrm{pH}$, condutividade, temperaturas do ar e da água e oxigênio dissolvido (0D). Os moradores lembraram-se saudosos do córrego Engole Cobra de outrora, cujas águas serviram para abastecimento de suas casas, lazer e pesca, mas que hoje representa para eles uma preocupação devido ao mau cheiro e à proliferação de vetores. Entre os parâmetros físico-químicos, os que melhores indicaram a sua elevada degradação, especialmente pelo despejo de efluentes

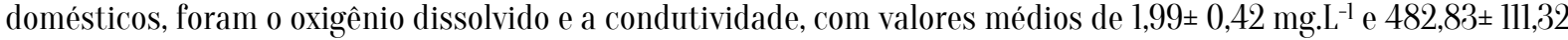
$\mu \mathrm{S} . \mathrm{cm}^{-1}$, respectivamente. Conclui-se que o córrego Engole Cobra, a exemplo dos outros córregos do município, encontra-se em situação de descaso por parte da gestão pública, sendo necessárias medidas de educação ambiental, de coleta e de tratamento de esgotos dos bairros circunvizinhos.

Palavras-chave: Qualidade da água, Córregos urbanos, Saneamento básico, Efluentes domésticos, Oxigênio dissolvido.

\section{Physico-chemical analysis and environmental perception of stream "Engole Cobra" in the city of Cuiabá-Mt, Brazil}

\begin{abstract}
The city of Cuiabá may be considered privileged from the point of view of water resources. However, rapid urbanization and economic growth of the capital, from the 70s, affected the quality of these resources, especially its urban streams. In this context is inserted stream Engole Cobre, one of the 30 urban streams of Cuiabá. The aim of this study was to analyze the quality of stream Engole Cobra water and assess the level of environmental awareness of its surroundings residents. For the perception evaluation, a semi structured questionnaire was applied to record historical and social importance of the stream in these people lives. The physicochemical parameters evaluated for the water quality were $\mathrm{pH}$, conductivity, air and water temperatures and dissolved oxygen (D0). Residents remembered stream Engole Cobra of yore longingly. Its waters served to supply their homes, leisure and fishing, but now the stream is for them a concern due to its bad smell and the proliferation of vectors. Among the physicochemical parameters, the ones which best indicated the stream high degradation were, especially due to dumping of domestic waste, dissolved oxygen and conductivity, with average values of $1.99 \pm 0.42 \mathrm{mg} \mathrm{L}^{-1}$ and $482,83 \pm 111.32 \mu \mathrm{S} . \mathrm{cm}^{-1}$, respectively. It was concluded that stream Engole Cobra, like the other streams of the city, is neglected by the public management, requiring environmental education measures and collection and treatment of sewage from surrounding neighborhoods.
\end{abstract}

Keywords: Water quality, Urban streams, Basic sanitation, Domestic effluents, Dissolved oxygen. 


\title{
Análisis físico-química y percepción ambiental del arroyo "Engole Cobra" en el municipio de Cuiabá-Mt, Brasil
}

\begin{abstract}
Resumen: El municipio de Cuiabá puede considerarse privilegiado desde el punto de vista de sus recursos hídricos. Sin embargo, la acelerada urbanización y el crecimiento económico de la capital, a partir de los años 70, afectaron la calidad de esos recursos, especialmente de sus corrientes urbanas. En ese contexto se encuentra el arroyo "Engole Cobra”, uno de los más de 30 arroyos urbanos de Cuiabá. El objetivo de este trabajo fue analizar la calidad del agua del arroyo "Engole Cobra" y evaluar el nivel de percepción ambiental de los habitantes de su entorno. Para la evaluación de la percepción de la población, se aplicó un cuestionario semiestructurado para registrar histórica y socialmente la influencia del arroyo para la vida de esas personas. Los parámetros físico-químicos evaluados para la calidad del agua fueron $\mathrm{pH}$, conductividad, temperaturas del aire y del agua y oxígeno disuelto (OD). Los habitantes recuerdan la importancia de este arroyo antiguamente, pues sus aguas sirvieron para abastecer sus casas, para entretención y pesca, pero hoy, representa para ellos una preocupación por el mal olor y la proliferación de vectores de enfermedades. Entre los parámetros físico-químicos, los que mejor indicaron su elevada degradación, especialmente por el vertido de efluentes domésticos, fueron el oxígeno disuelto y la conductividad, con valores medios de 1,99 \pm 0,42 mg. $\mathrm{L}^{-1}$ y $482,83 \pm 111,32 \mu \mathrm{S} . \mathrm{cm}^{-1}$, respectivamente. Se concluye que el arroyo Engole Cobra, a ejemplo de los otros arroyos del municipio, se encuentra en situación de descuido por parte de la gestión pública, siendo necesarias medidas de educación ambiental, de recolección y de tratamiento de aguas residuales de los barrios circundantes.

Palabras clave: Calidad del agua, Corrientes urbanas, Saneamiento básico, Efluentes domésticos, 0xígeno disuelto.
\end{abstract}

\section{INTRODUÇÃ0}

0 modelo industrial e tecnológico estabelecido a partir do século XX resultou em uma sociedade consumista, criando inúmeros problemas ambientais vinculados à forma como os espaços são produzidos e como a sociedade se apropria da natureza. Isto porque o homem, durante a sua trajetória, estabeleceu a ocupação e o uso espacial da terra, apossando-se dos recursos naturais renováveis e não renováveis. Com o decorrer do tempo, passou a adotar um comportamento predatório em relação à natureza (MAGALHÃES e WERLE, 2009).

No Brasil, desde o êxodo rural dos anos 50, as cidades têm crescido sem infraestrutura e disponibilidade de serviços urbanos capazes de comportar o contingente populacional que recebem. Esse resultado tem provado a ineficácia da intervenção do Estado em atender demandas sociais na área habitacional e de saneamento básico. As habitações desordenadas causam a degradação ambiental, que atinge recursos imprescindíveis para a existência e manutenção da vida, como a água, o solo e o ar (MARICAT0, 2000; BELIZÁRIO, 2014).

Conforme Baptista et al. (2005), a urbanização implica, forçosamente, em alterações significativas no meio ambiente de forma geral e nos processos hidrológicos, em particular por meio da ação direta nos cursos d’águas e nas bacias hidrográficas como um todo. 
Os recursos hídricos no meio urbano estão relacionados com 0 abastecimento da população. Porém, o crescimento demográfico e a densificação da ocupação urbana, especialmente no entorno dos corpos hídricos, fizeram com que as condições ambientais desses mananciais se tornassem inadequadas. A poluição das águas naturais pode ser atribuída ao lançamento de efluentes domésticos e industriais e à introdução de substâncias naturais ou artificiais (REBOUÇAS et al., 2006), o que torna o tratamento para o abastecimento público muito mais caro e complexo.

A água é o único recurso natural que envolve todos os aspectos da civilização humana, desde o desenvolvimento agrícola e industrial aos valores culturais e religiosos arraigados na sociedade. Quando se trata de atender às necessidades básicas dos seres humanos e do meio ambiente, a sua qualidade é tão importante quanto a sua quantidade (BRIT0 et al., 2012).

0 município de Cuiabá é banhado pelo rio Cuiabá, que faz parte da bacia hidrográfica do Rio Paraguai, e pode ser considerada uma cidade privilegiada do ponto de vista de recursos. Contudo, a acelerada urbanização e o crescimento econômico desse município, a partir dos anos 70, afetaram a qualidade de seus recursos hídricos. 0s córregos dessa capital, que poderiam servir de local para recreação e bem-estar da população, são esgotos, pois nestes são dispensados, sem nenhum ou pouco tratamento, despejos domésticos e industriais (BORDEST, 2003).

No contexto apresentado está inserido o córrego Engole Cobra, um dos mais de 30 córregos urbanos de Cuiabá, objeto de estudo do presente trabalho. 0 objetivo desta pesquisa foi avaliar o nível de percepção ambiental e registrar histórica e socialmente a importância do córrego Engole Cobra para a vida dos moradores circunvizinhos. Ainda, objetivou analisar a qualidade do córrego por meio de parâmetros físico-químicos.

\section{MATERIAL E MÉTODOS}

\section{Área de Estudo}

Cuiabá situa-se na província geomorfológica denominada Depressão Cuiabana (15¹0’ a

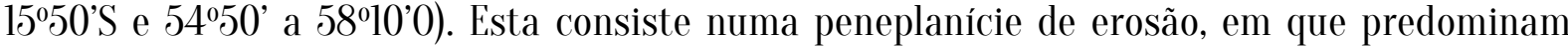


Análise físico-química e percepção ambiental do córrego Engole Cobra no município de Cuiabá-MT

relevos de baixas amplitudes. Sua principal fitofisionomia é de Cerrado. Na área urbana, as altitudes variam de 146 a 259 metros (CUIABÁ, 2009).

0 clima da bacia do rio Cuiabá é classificado como tropical quente semiúmido, com sazonalidade marcada por dois períodos bem distintos, seco (outono-inverno) e chuvoso (primavera-verão). A temperatura média anual em Cuiabá varia de 24 a $29^{\circ} \mathrm{C}$ e a umidade relativa média do ar é de 78\%. Nos meses de outubro e novembro, as máximas atingem, muitas vezes, valores de $40^{\circ} \mathrm{C}$ com umidade relativa de $18 \%$ nas horas mais quentes do dia. A precipitação média anual varia entre $800 \mathrm{~mm}$ e $1.600 \mathrm{~mm}$, com as máximas ocorrendo nas cabeceiras. 0 ritmo sazonal de precipitação é marcado por uma estação seca bem definida no período de inverno. Entretanto, na estação chuvosa ocorrem violentas tempestades entremeadas por períodos de transição sob o calor do sol intenso (MAITELLI et al., 2004; LIBOS, 2008)

Dos 36 córregos de Cuiabá, a maioria já sofreu intervenções físicas ou algum tipo de obra de drenagem em seus cursos, como canalizações abertas ou fechadas em alguns intervalos. Entre os 5 principais córregos modificados estão: Barbado, Gambá, Prainha, Mané Pinto e Engole Cobra, sendo este último o objeto de estudo do presente trabalho (GALDIN0 e ANDRADE, 2008; SALES, 2009).

0 córrego Engole Cobra encontra-se localizado na zona oeste da cidade de Cuiabá, situado entre os bairros Porto, Cidade Alta e o antigo bairro Pólvora, hoje, bairro Goiabeiras. Esses bairros, além de terem considerável número de habitantes para o padrão local, possuem também um valor histórico importante, tanto que o bairro Porto marcou no século XIX a divisão do município em dois grandes bairros: "Porto" e "Cidade” (MARTINS Jr., 2000).

Segundo Araújo (2010), o córrego Engole Cobra tem uma extensão total de 617,51 metros. Todo o córrego está canalizado, sendo que uma parte é fechada e, outra, aberta. A parte aberta encontra-se na avenida. Dr. José Feliciano Figueiredo em confluência com a Avenida Senador Metelo, até sua foz com o Córrego Mané Pinto, que fica na Avenida 8 de abril. Este último deságua no Rio Cuiabá (Figura 1). À esquerda, foto do local de pesquisa (Autores) e, à direita, hidrografia do município de Cuiabá, com destaque para o córrego Engole Cobra. Em azul: leito natural; em verde: canalizado aberto; em vermelho: canalizado fechado. 


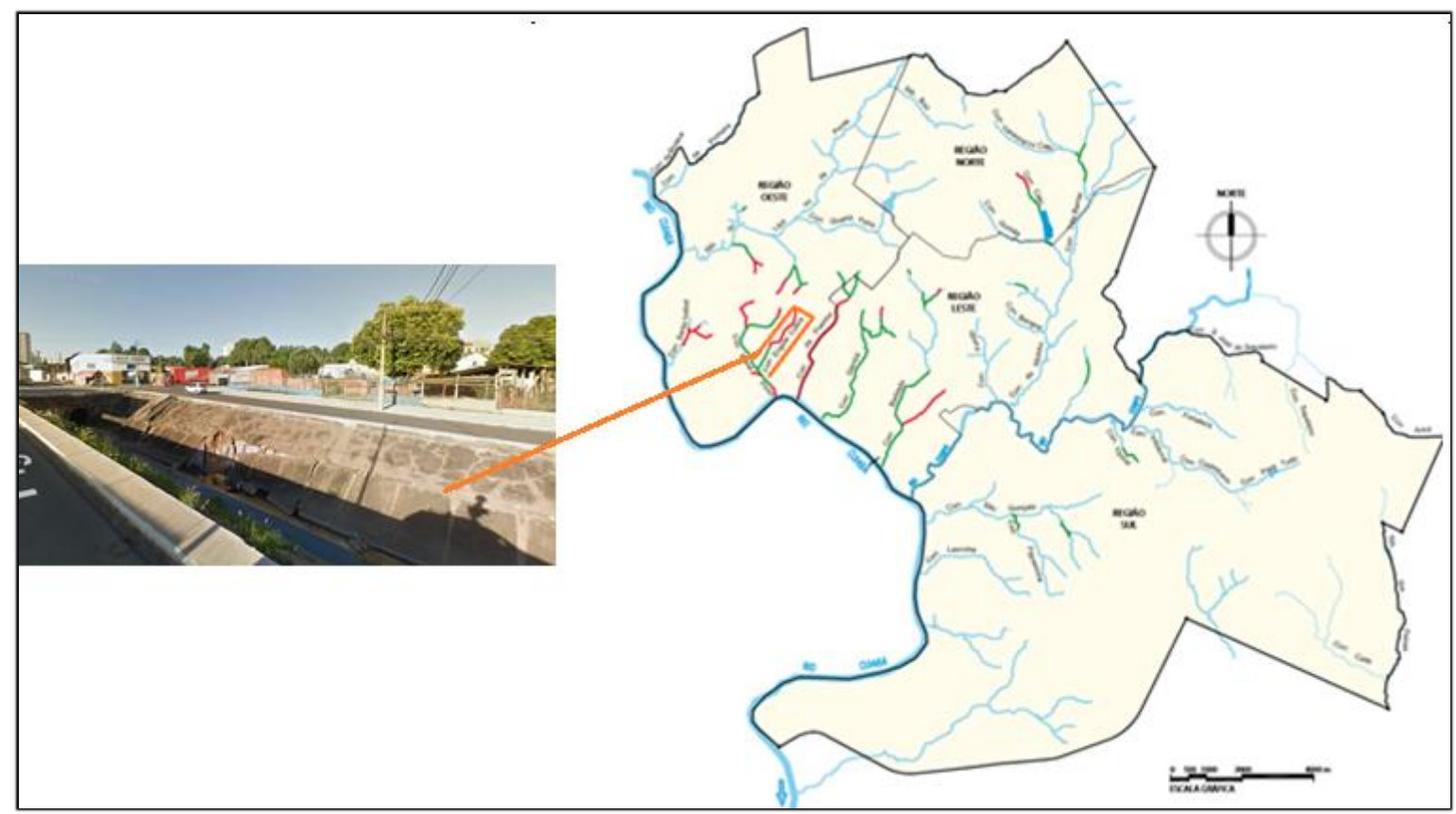

Figura 1. Localização do córrego Engole Cobra

Fonte: Perfil sócio econômico de Cuiabá, vol IV, /IPDU, 2009 adaptado.

Ao longo de sua extensão, observam-se condomínios residenciais e comércios, além de tráfego intenso de veículos, contribuindo com a degradação e o depósito inadequado de vários tipos de resíduos. Ainda, observa-se o despejo de esgotamento sanitário sem tratamento adequado, ou seja, o córrego Engole Cobra exerce a função de mais um receptáculo de efluentes domésticos sem tratamento dos moradores circunvizinhos.

\section{Coletas das amostras de água e entrevistas}

Houve preliminarmente uma visita de campo para levantamento visual e descritivo das características físicas do córrego e contato inicial com a população circunvizinha.

A execução do experimento foi dividida em sete etapas, todas in loco. A primeira foi realizada para observação, caracterização e marcação dos pontos onde seriam realizadas as amostragens de acordo com a NBR 9897 (ABNT, 1987). Nas outras seis etapas, foram realizadas as coletas e análises físico-químicas e entrevistas, visto que para analisar a qualidade ambiental urbana é necessário considerar vários componentes da paisagem, tanto relacionados aos aspectos físicos como aos sociais (LIMA, 2014). 
Análise físico-química e percepção ambiental do córrego Engole Cobra no município de Cuiabá-MT

As coletas de água do córrego Engole Cobra para análises físico-químicas foram realizadas em 3 pontos (Figura 2) nas seguintes datas do ano de 2015: 29 de maio (final do período chuvoso); 05 e 13 de junho (período de seca); 29 de agosto (período de seca); e 19 de novembro (início do período chuvoso). Em 2016, a coleta ocorreu em 03 de fevereiro (período chuvoso). Os pontos foram escolhidos dentro da extensão aberta do córrego até sua foz. Além disso, a coleta foi feita considerando os períodos de estiagem e de chuva. Os parâmetros físicoquímicos analisados foram temperatura do ar, temperatura da água, potencial hidrogeniônico (pH), oxigênio Dissolvido (OD) e condutividade.

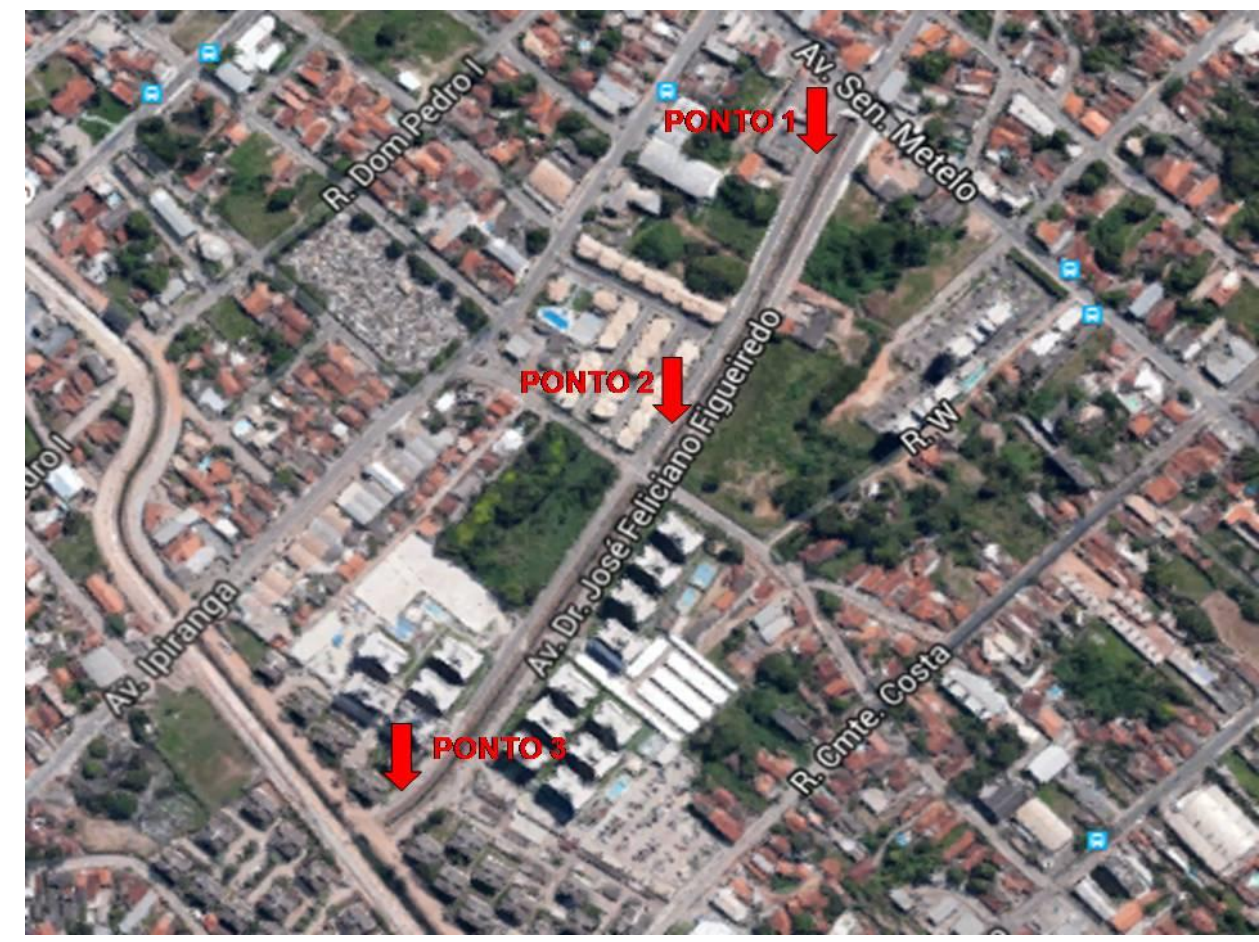

Figura 2. Identificação dos pontos de coleta do córrego Engole Cobra, Cuiabá-MT Fonte: Google Maps, 2015 adaptado.

Devido à dificuldade para se alcançar o córrego, as coletas foram realizadas usando um balde com auxílio de uma corda (Figura 3A), de acordo com a NBR 9898 (ABNT, 1987). As medidas dos parâmetros físico-químicos-analisados foram obtidas pelo método eletrométrico, por meio do aparelho multiparâmetros do fabricante Hanna, modelo HI 9828 (Figura 3B). 


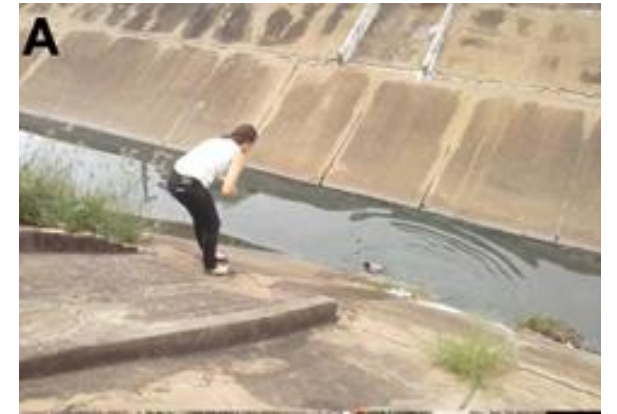

Coleta de água com auxílio de balde e corda

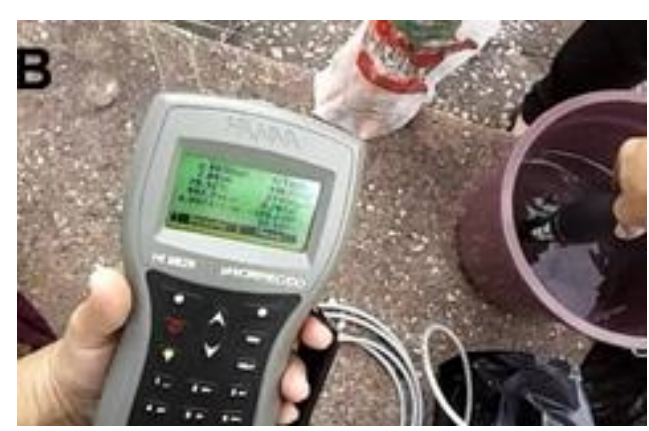

Medidas físico-químicas pelo método eletrométrico com aparelho multiparâmetro

Figura 3. Coleta e medição físico-química no Córrego Engole Cobra, Cuiabá-MT Fonte: Autores.

Os dados de precipitação foram obtidos do Banco de Dados Meteorológicos para Ensino e Pesquisa, registrados no Instituto Nacional de Meteorologia (INMET), que se localiza a aproximadamente 2,7 Km do córrego estudado.

A coleta de dados sobre a percepção ambiental dos moradores foi feita com a população circunvizinha, dos bairros Goiabeiras e Porto, utilizando-se de entrevistas semiestruturadas com questões abertas e fechadas (BONI e QUARESMA, 2005). 0 critério para a seleção das pessoas entrevistadas foi a proximidade das moradias com o córrego. A prioridade foram os moradores antigos da região, que sabiam do histórico do córrego Engole Cobra, o que o córrego representava e representa para a região, onde se localiza a sua nascente e qual a procedência do seu nome.

Antes de cada entrevista, houve a identificação dos pesquisadores e a explicação dos objetivos do trabalho. Cada participante assinou o Termo de Anuência Prévia, livre e esclarecido, para que suas informações pudessem ser utilizadas. As entrevistas continham questões que abordaram aspectos socioeconômicos, qualidade ambiental e a relação dos moradores com 0 ambiente local.

A abordagem metodológica aplicada foi a história oral, que privilegia a realização de entrevistas com pessoas que participaram ou testemunharam acontecimentos, conjunturas e visões de mundo, de maneira a se aproximar do objeto de estudo (ALBERTI, 1989). Dentre as modalidades de história oral, classificadas por Meihy (2002), optou-se pela história oral 
Análise físico-química e percepção ambiental do córrego Engole Cobra no município de Cuiabá-MT

temática, visto que a pesquisa partiu de um assunto específico e preestabelecido e por ser a que mais permite articular o diálogo com outros documentos e fontes de coleta.

Vale ressaltar que a fala do entrevistado foi respeitada e foi reproduzida a transcrição ipsis litteris, de forma que até a grafia de palavras não dicionarizadas ou vícios de linguagem permanecessem intocados, preservando-se os sentidos atribuídos pelo depoente, como recomenda Almeida (2012).

\section{Coletas das amostras de água e entrevistas}

As médias dos parâmetros físico-químicos dos pontos amostrais (tratamentos) foram submetidas aos testes de normalidade (Lilliefors), homogeneidade (Cochran) e Análise de Variância (ANOVA). Caso na ANOVA fosse observada diferença estatisticamente significativa entre as médias (teste F), elas seriam submetidas ao teste de média (Tukey) a $5 \%$ de probabilidade. Caso a ANOVA não demonstrasse diferença estatisticamente significativa, os valores das variáveis seriam apresentados em variação temporal, de acordo com as datas das coletas. Utilizou-se como software estatístico o programa ASSISTAT versão 7.7 (SILVA, 2013).

Para a análise das respostas descritivas das entrevistas foi utilizada a percentagem, calculada com o auxílio do Microsoft Excel versão 2010.

\section{RESULTADOS E DISCUSSÃ0}

\section{Percepção dos moradores}

Devido ao difícil acesso e grande quantidade de condomínios fechados no entorno do córrego, que foi observado na nossa visita preliminar ao local, foram convidados a participar da entrevista oito pessoas, com faixa etária de 40 a 80 anos, que se mostraram disponíveis a colaborar com a pesquisa. 0 nível de escolaridade variou de ensino fundamental incompleto à pós-graduação. Somente um entrevistado não reside mais na região, enquanto os demais residem nos bairros Goiabeiras (antigo Pólvora) e bairro Porto. Vale ressaltar que esses moradores antigos preferem e adotam ainda o nome de bairro Pólvora. 
Nas entrevistas realizadas, observou-se divergência entre os entrevistados quando perguntados a respeito da origem do nome do córrego Engole Cobra e sobre onde fica sua nascente.

Segundo o senhor J. L. S. (67 anos), nascido e criado em Cuiabá e que conhece o córrego Engole Cobra desde criança, o córrego tinha uma diversidade de nomes, como Bate Bronca, Custa-me Ver e Curral Velho. Contudo, segundo ele, o nome que sempre predominou foi Engole Cobra, mas nunca soube sua origem. Dos entrevistados, 37\% não sabiam da origem do nome Engole Cobra, 37\% afirmaram que o nome do córrego é devido ao grande número de cobras que havia na região, 13\% disseram que o córrego levou esse nome devido ao hábito alimentar de um senhor que morava na sua cabeceira e 13\% apresentaram a versão de que o córrego foi assim nomeado devido ao fato de que, outrora, alguns moradores homossexuais da região não expunham sua orientação sexual.

Entre os entrevistados, 50\% afirmaram que o córrego Engole Cobra tem sua nascente nas proximidades da Praça Popular (bairro Popular), região oeste, 37,5\% não sabiam onde está sua nascente, $6,25 \%$ afirmaram que a nascente fica próxima ao rio Coxipó (entre as regiões leste e sul) e 6,25\% disseram que sua nascente se encontra próxima ao Parque Mãe Bonifácia (Gráfico 1), que é um parque urbano de Cuiabá, também localizado na região oeste.

Gráfico 1 - Respostas dos entrevistados quanto ao local da nascente do córrego Engole Cobra, Cuiabá-MT

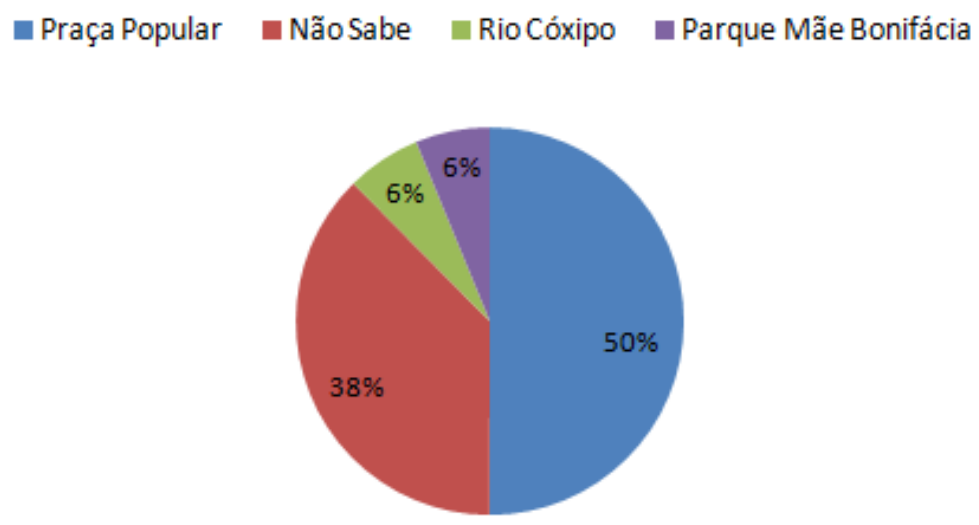

Fonte: Dados obtidos das entrevistas pelos autores. 
Primeiramente, buscamos no relatório e mapas referentes ao projeto de "Caracterização e delimitação cartográfica das áreas de preservação permanente (APP's) e de zonas de interesse ambiental (ZIA’s) na área urbana de Cuiabá" (IPEM, 2008) a localização da nascente do córrego Engole Cobra; porém, esta não está registrada no documento. Desta forma, apresentamos a visão histórica da nascente do Córrego.

Segundo Franklin et al. (2015), a nascente do Córrego Engole Cobra era em uma "lagoinha” na Praça Clóvis Cardoso, pertencente ao bairro Goiabeira, antigo bairro Lava-Pés, onde os tropeiros lavavam seus pés ao chegarem de suas viagens.

\begin{abstract}
0 atual bairro Goiabeira já foi chamado de Lava-Pés. Acontece que quando os tropeiros vindos das localidades de Nobres, Rosário Oeste, Brotas e Guia chegavam por aqui, pegavam a rua Senador Azeredo (atual 24 de 0utubro) e só faziam parada na praça Clóvis Cardoso, que se chamava "Mãe dos Homens", porque a igreja de igual nome ficava nesta praça, e após ser demolida veio a ser reconstruída próximo à praça Santos Dumont. Neste local tinha uma lagoinha que é a nascente do córrego Engole Cobra, onde a tropa descia para lavar os pés... (Almanaque Cuiabá, 2015, 18p.).
\end{abstract}

Quando questionados sobre o que o córrego representava em suas vidas no passado, observaram-se informações distantes da realidade atual, como, por exemplo, seu uso para lavagem de roupas, recreação, pesca e caça.

\footnotetext{
“Gostava do córrego, criança brincava dentro dele. Naquela época, era água natural, não tinha tanto esgoto desabando nele. A gente tomava banho escondido de mamãe.” (E. G., 46 anos)

"Antigamente, eu sinto até falta desse corguinho... Matava sinimbul, a gente
comia, e matava." (D. P., 42 anos)
}

Sobre o que ele representa hoje, alguns falaram que representa um risco para a saúde, mau cheiro, proliferação de insetos e doenças como a dengue, e outros ainda, com tristeza, falaram que ele representa apenas uma lembrança boa que nunca mais vai voltar. Todos os entrevistados disseram que não usam o córrego para nada mais.

\footnotetext{
${ }^{1}$ Espécie de lagarto.
} 
"Hoje o córrego só representa lembrança, porque hoje eu não desço mais pra lá, não vejo a água passar, eu não tenho mais acesso. Ai na hora que tampar pra lá, que tem projeto pra tampar, ai acaba a lembrança.” (E. G., 46 anos)

Nenhum dos entrevistados utilizava e utiliza a água do córrego para consumo, mas outros já a usaram. 0 Sr. J. B. (78 anos) afirmou que, cerca de 40 anos atrás, algumas pessoas que moravam distantes utilizavam baldes e charretes para levar água, que era cristalina, às casas mais longínquas. A água era armazenada em potes e baldes, e era filtrada somente em pano para retirar os resíduos maiores. Posteriormente, era colocada em moringas para uso diário. Todos os entrevistados afirmaram que na infância deles a água não continha cheiro ou cor, era cristalina.

Hoje o abastecimento da região é feito pela concessionária dos serviços de água e esgoto de Cuiabá - CAB (Companhia de Águas do Brasil). Todos os entrevistados afirmaram que não há falta de água na região. Eles têm caixas d'água e relataram que as lavam periodicamente. Disseram, ainda, que a água consumida pela família é procedente de garrafões de água mineral, filtros e purificadores de água.

Quando questionados quanto à existência da fauna aquática e terrestre, todos afirmaram que não existem mais peixes no local e, segundo os entrevistados, o córrego hoje atrai animais peçonhentos como serpentes, escorpiões e aranhas, além de vetores, como baratas, ratos e mosquitos. A Sr. ${ }^{\text {a }}$ E. M. (60 anos) afirmou que o maior risco à saúde que o córrego traz é a proliferação do mosquito da dengue, muito comum em Cuiabá.

Segundo Pinto (2010), o processo de urbanização causa desequilíbrio ecológico em ecossistemas naturais ainda não alterados por ação antrópica. Um exemplo é a retirada da mata ciliar para a canalização do córrego. Ela tem importante função ambiental na manutenção da qualidade da água, na estabilidade dos solos e na regularização dos ciclos hidrológicos. Também, é uma das responsáveis pela conservação da biodiversidade (REIS e R0GALSKI, 2006) e pelo não aparecimento da fauna sinantrópica. Tal fauna indesejável também foi citada pela população em outros córregos urbanos de Cuiabá, como a do entorno do córrego Barbado (KREISCHER et al., 2012).

Não existe coleta seletiva de lixo na região, porém a coleta é feita regularmente e todos os entrevistados estão satisfeitos quanto a isso. Segundo a entrevistada Sr. a. E. G. (46 anos), mesmo com a coleta de lixo em três dias da semana, ainda existem pessoas que jogam materiais 
Análise físico-química e percepção ambiental do córrego Engole Cobra no município de Cuiabá-MT

diretamente no córrego, como sofás, colchões e animais mortos. A coleta de resíduos sólidos é feita atualmente pelo grupo empresarial Ecovap Soluções Urbanas.

Quando questionados sobre a coleta de esgoto, 25\% possuem fossas sépticas e 75\% dizem ter coleta de esgoto feita pela prefeitura. Destes, $50 \%$ acreditam que o esgoto coletado vai para o córrego (Gráfico 2).

"...Todo esgoto da casa, quando a construtora foi fazer, pediu que os moradores fizessem a canalização para desbocar o bueiro nele (córrego Engole Cobre)."(E. G. , 46 anos)

A CAB Cuiabá é a concessionária responsável pela coleta e tratamento de esgotos do município, porém não há dados atuais disponibilizados pela empresa sobre a cobertura de coleta e tratamento de esgotos. De acordo com informações do Plano Municipal de Saneamento Básico (Cuiabá, 2011), o sistema de esgotamento sanitário atende aproximadamente 38\% da população, sendo que somente $28 \%$ contam com os serviços de coleta e tratamento.

Gráfico 2 - Resposta dos entrevistados quanto à coleta de esgoto da região no entorno do córrego Engole Cobra, Cuiabá-MT

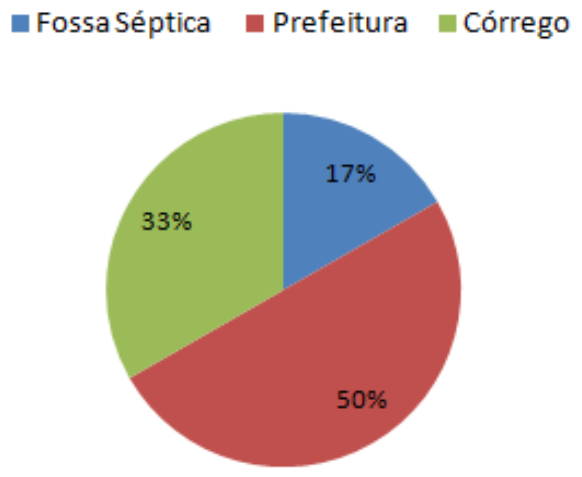

Fonte: Dados obtidos das entrevistas pelos autores.

Em Cuiabá o descaso do poder público quanto à coleta e tratamento de esgoto é um problema muito antigo. Serilo et al. (2014) também observaram, em pesquisa com idosos sobre o saneamento básico no município, a relação afetiva dos antigos moradores com os córregos da cidade. Os mananciais eram utilizados para diversos fins, tais como para consumo (água para beber e banhar), recreação, pesca e lavagem de roupas. A tristeza das pessoas também foi 
registrada ao verem que os córregos se tornaram receptáculos de águas servidas e resíduos da população, ou simplesmente são canalizados e tampados para que não se veja o que acontece por baixo dos concretos.

\section{Parâmetros físico-químicos das amostras}

Os dados apresentaram homocedasticidade, porém não houve diferença estatisticamente significativa entre os valores das temperaturas do ar e da água, do pH, do Oxigênio Dissolvido (OD) e da condutividade, analisados nos pontos amostrais pela ANOVA. Portanto, os resultados serão apresentados usando a estatística descritiva básica (média e desvio padrão) e os valores ao longo do tempo em relação aos períodos de seca e chuva do local.

No Gráfico 3 são apresentadas a precipitação média do município de 1970 a 2007 (Cuiabá, 2009), assim como a precipitação nos meses de coleta dos dados (INMET, BDMEP). Observa-se que, no ano de 2015, em maio e julho, houve uma precipitação acima da média histórica. Contudo, nos demais meses de coleta a precipitação foi menor, especialmente no mês de novembro. É um parâmetro importante a ser analisado, visto que com as chuvas há diluição da concentração de substâncias lançadas nos mananciais, além de alteração nas temperaturas do ar e da água, que por sua vez influenciam nas reações químicas que acontecem com essas substâncias.

Nos dias de coletas observaram-se materiais flutuantes, resíduos sólidos (dentre eles, garrafas pets e sacos de lixos) dispostos ao longo do córrego e forte odor, que foi mais acentuado no período de estiagem.

Gráfico 3 - Precipitação média nos anos de 1970 a 2007 e nos meses de coleta de dados no córrego Engole Cobra, Cuiabá-MT 


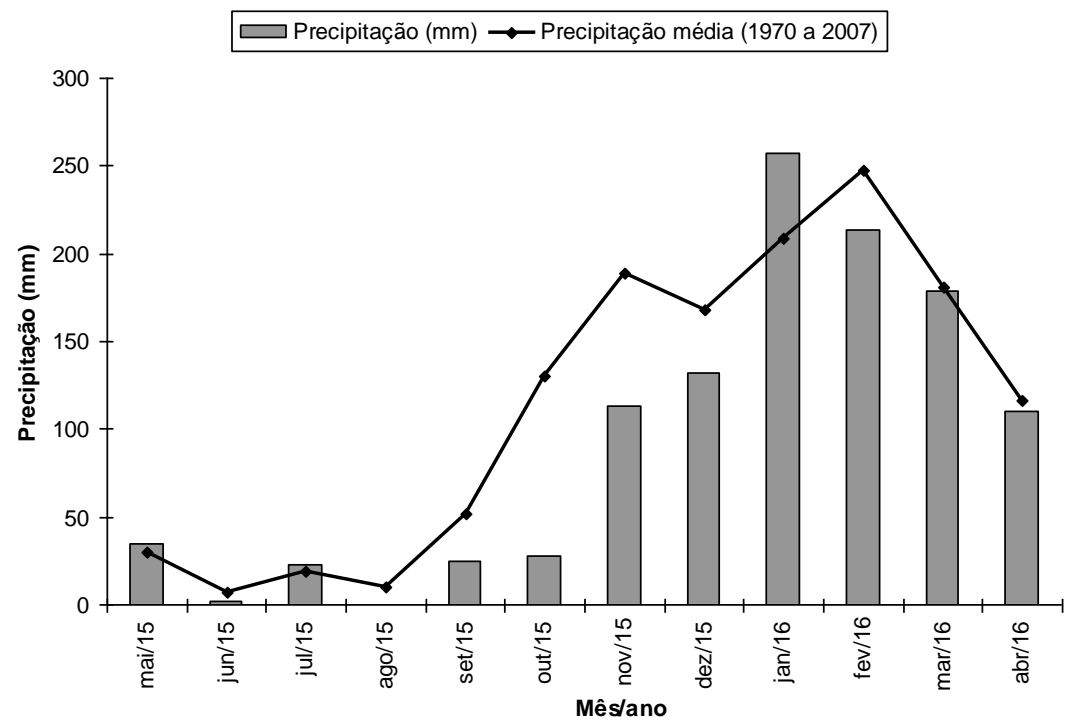

Fonte: Prefeitura Municipal de Cuiabá (2009) e INMET (2016).

\section{Temperatura do ar e da água}

No Gráfico 4 são apresentados os valores das temperaturas do ar e da água medidos nos três pontos de coleta (P1, P2 e P3) do córrego Engole Cobra nas datas de amostragem. A média da temperatura do ar de todos os pontos nas datas de coleta foi $30,43 \pm 0,35{ }^{\circ} \mathrm{C}$. A média da temperatura da água foi ligeiramente maior que a do ar, 30,71 $\pm 0,69{ }^{\circ} \mathrm{C}$, com maior variação entre os pontos. Isso pode ser explicado pelo fato de que o canal do córrego está concretado e não há mais mata e nem vegetação ciliar protegendo o leito do córrego.

0 maior valor registrado, respectivamente, das temperaturas do ar e da água, $34,83 \pm 0,67$ ${ }^{\circ} \mathrm{C}$ e $34,97 \pm 0,55^{\circ} \mathrm{C}$, ocorreram no mês de agosto, o mais seco do ano, em que não houve registro de nenhuma precipitação no local. Vale ressaltar que a temperatura exerce influência marcante na velocidade das reações químicas, nas atividades metabólicas dos organismos e na solubilidade de substâncias; portanto, nos demais parâmetros que serão descritos a seguir.

Matheus et al. (1995) citaram que a maioria das espécies animais e vegetais têm exigências definidas quanto às temperaturas máximas e mínimas toleradas, sendo que as variações de temperatura da água, parte do regime climático natural, influenciam o metabolismo de comunidades aquáticas, como a produtividade primária, a respiração dos organismos e a decomposição da matéria orgânica. 
Gráfico 4 - Temperaturas do ar e da água nas datas de coletas nos três pontos amostrais do córrego Engole Cobra, Cuiabá-MT

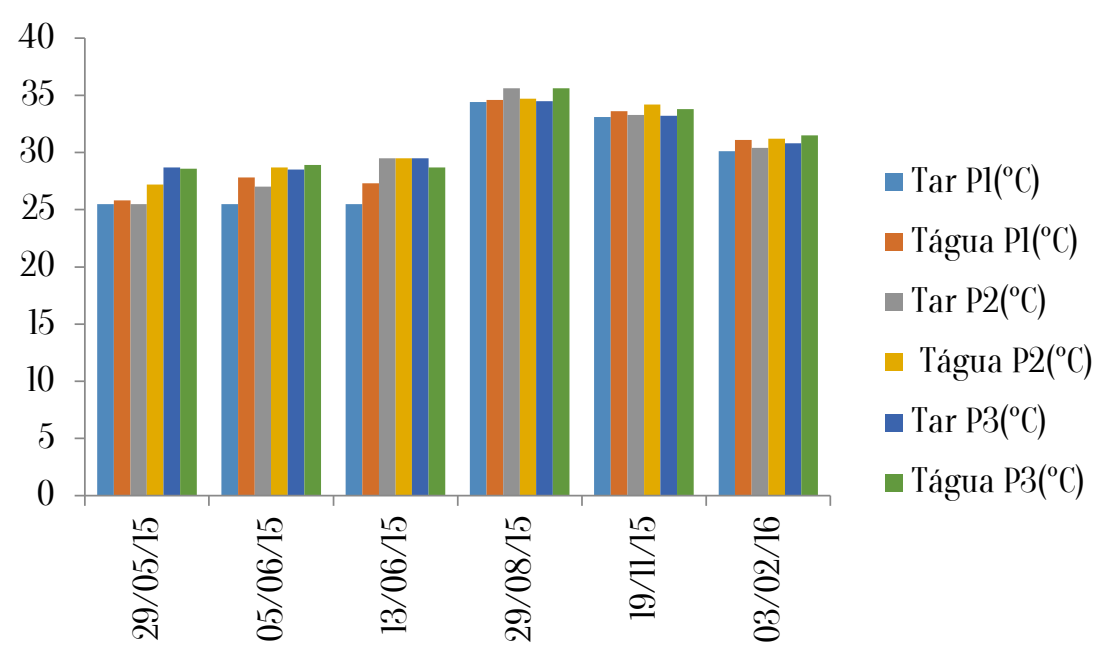

Fonte: Dados coletados in loco pelos autores.

\section{Potencial Hidrogeniônico (pH)}

Segundo Zuin et al. (2009), o pH, juntamente com outros parâmetros, pode fornecer indícios do grau de poluição, do metabolismo de comunidades ou ainda de impactos em um ecossistema aquático. A média do pH em todos em pontos nas datas de coleta foi 7,08ะ0,26.

Com base no baixo 0D apresentado e na faixa de pH observada, foi possível constatar que o principal processo de decomposição da matéria orgânica que ocorre no Córrego Engole Cobra é o anaeróbio. De acordo com Zumach (2003), os diferentes grupos de bactérias podem apresentar faixas ótimas de $\mathrm{pH}$ com valores diferentes. No caso das bactérias anaeróbias produtoras de metano, seu crescimento ótimo ocorre na faixa de pH entre 6,8 e 7,4, que está de acordo com os valores medidos nas datas de coleta, com variações médias que estão entre 6,67士 0,23 (mês de agosto) e 7,38ะ0,35 (mês de junho) (Gráfico 5).

Portanto é importante analisar sob outros aspectos os resultados obtidos de pH, além do padrão estipulado pela legislação CONAMA 357/05, que para rios de água doce, classe II, é de 6 a 9, para não incorrer na ideia de um córrego em boas condições ambientais. 
Análise físico-química e percepção ambiental do córrego Engole Cobra no município de Cuiabá-MT

Gráfico 5 - pH da água nas datas de coletas nos três pontos amostrais do córrego Engole Cobra, Cuiabá-MT

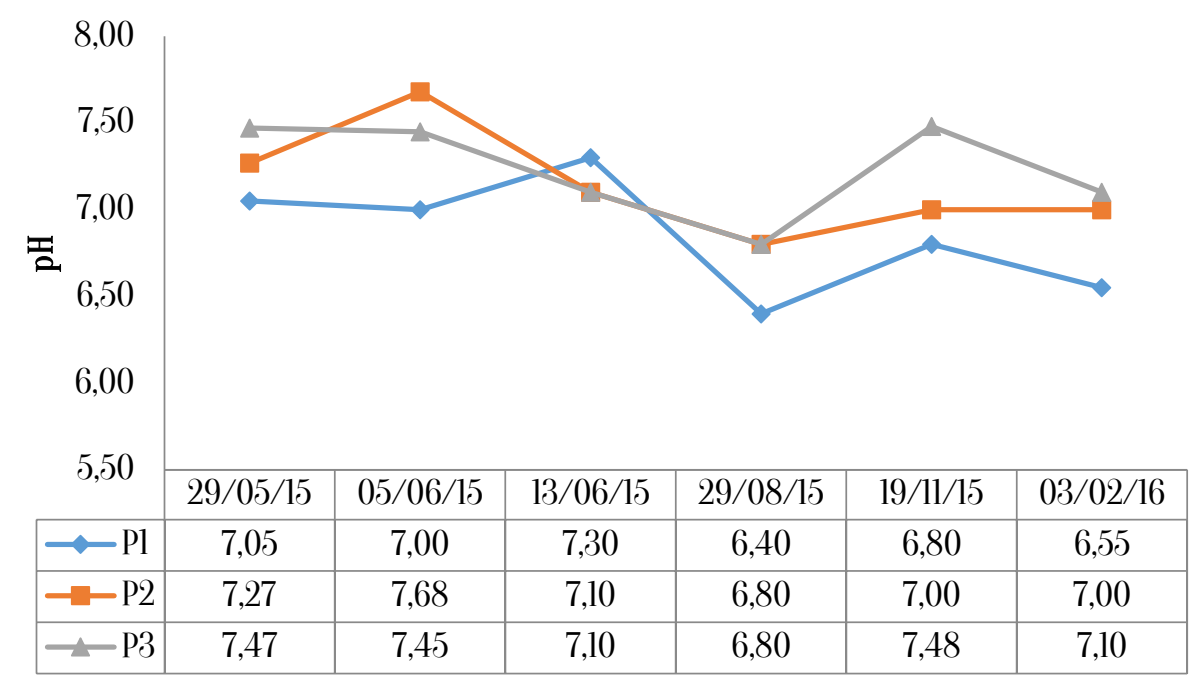

Fonte: Dados coletados in loco pelos autores.

0 mês de agosto teve o menor valor de $\mathrm{pH}$, apontando que na estiagem a água do córrego Engole Cobra ficou ligeiramente ácida. Isso mostra que os efluentes lançados no seu leito têm caráter ácido e que, no período chuvoso, o pH aumenta em função da diluição dessas substâncias.

No mesmo mês ocorreram as maiores temperaturas da água, o que implica a intensificação da taxa de decomposição da matéria orgânica lançada no córrego (BUZELLI e CUNHA-SANTIN0, 2013), e, consequentemente, a diminuição do pH. Segundo Guimarães e Nour (2001), a decomposição realizada pelos microrganismos anaeróbios (metanogênese e sulfetogênese) tem como produtos o metano e o gás sulfídrico. Os anóxicos (desnitrificação), por outro lado, produzem o gás nitrogênio. Contudo, independente de serem anaeróbios ou anóxicos, ambos produzem juntamente o gás carbônico, o que implica na diminuição do pH do meio aquático.

A elevação da temperatura provoca maior intensidade do odor que exala da água, conforme reclamação dos entrevistados. 0 aumento da intensidade acontece devido às substâncias liberadas nas reações anaeróbias de decomposição, em especial o metano e o gás sulfídrico. 


\section{Condutividade}

A condutividade elétrica da água é determinada pela presença de substâncias dissolvidas que se dissociam em ânions e cátions. É a capacidade da água de transmitir corrente elétrica. 0 parâmetro é um indicativo da concentração total de substâncias ionizadas em solução aquosa (MACED0, 2004), ou seja, não determina quais os íons presentes na amostra de água, mas pode contribuir para possíveis reconhecimentos de impactos ambientais que ocorram no corpo hídrico (ZUIN et al., 2009). A resolução 357/05 do CONAMA não preconiza limites aceitáveis de condutividade; todavia, nas águas naturais as medidas de condutividade elétrica são menores que $300 \mu \mathrm{S} . \mathrm{cm}^{-1}$, e a média encontrada nos rios de Mato Grosso é $40 \mu \mathrm{S} . \mathrm{cm}^{-1}$ (MARTINS, 2010). De acordo com a CETESB - Companhia de Tecnologia de Saneamento Ambiental (2009), os níveis superiores a $100 \mu \mathrm{s} / \mathrm{cm}$ indicam ambientes impactados negativamente.

A média do valor da condutividade em todos os pontos nas datas de coleta foi $482,83 \pm$ 111,32 $\mu{\mathrm{S} . \mathrm{cm}^{-1}}^{-}$Como a condutividade varia com a temperatura e a concentração dos íons e depende da quantidade de esgoto lançado, observa-se considerável variação entre as amostras.

No Gráfico 6 são apresentados os valores da condutividade nos pontos amostrais ao longo das coletas.

Gráfico 6 - Condutividade da água nas datas de coletas nos três pontos amostrais do córrego Engole Cobra, Cuiabá-MT

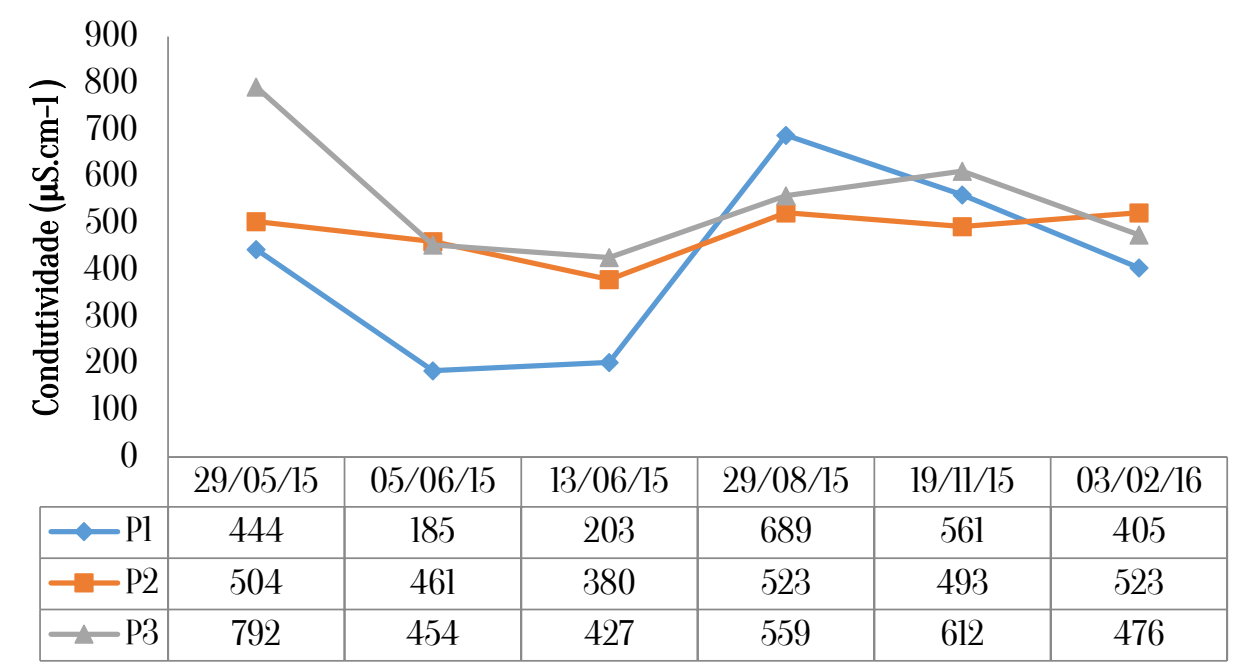

Fonte: Dados coletados in loco pelos autores. 
Análise físico-química e percepção ambiental do córrego Engole Cobra no município de Cuiabá-MT

Observa-se que o maior valor da condutividade ocorreu no mês de agosto, em que a média dos pontos foi $590,33 \pm 87,32 \mu \mathrm{S} . \mathrm{cm}^{-1}$. Como já descrito, nesse mês não houve precipitação e registrou-se a maior temperatura. Assim, além de a concentração de íons ser maior devido à menor vazão no leito do córrego, a elevação da temperatura também aumenta a condutividade. A temperatura exerce influência marcante na solubilidade de diversas substâncias químicas e, segundo Esteves (1998), a atividade iônica em uma solução aumenta $2 \%$ a cada grau celsius na temperatura.

Os valores de condutividade encontrados só corroboram o que foi visto e registrado: uma grande quantidade de esgotamento sanitário ao longo do córrego Engole Cobra, e que em sua maioria são despejos provenientes de residências que contribuem para a entrada de grande quantidade de íons no corpo d'água (Figura 4).

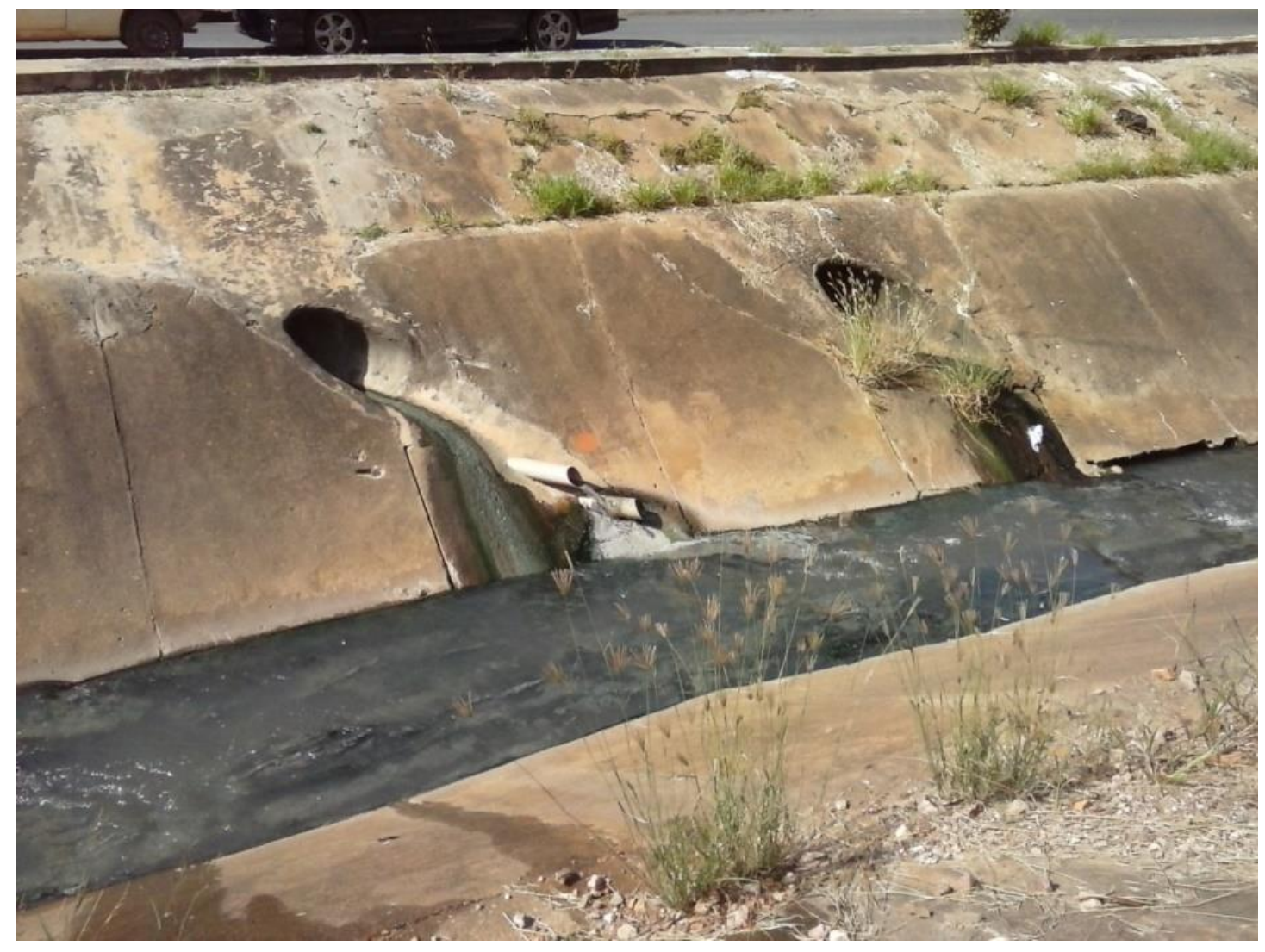

Figura 4. Lançamento de efluentes sem tratamento diretamente no córrego Engole Cobra, Cuiabá-MT

Fonte: Autores. 


\section{Oxigênio dissolvido (OD)}

Entre os gases dissolvidos em ambientes aquáticos, o oxigênio é o mais importante, sendo absolutamente indispensável à vida dos organismos aeróbios. Ele provém essencialmente da atmosfera, e é também produzido por reações de fotossíntese das plantas (ARRUDA et al., 2012). De acordo com a resolução do CONAMA 357/05 para rios de água doce, classe II, os valores de OD não devem ser inferiores a 5 mg. $\mathrm{L}^{-1}$.

As variações nos teores de oxigênio dissolvido estão associadas aos processos físicos, químicos e biológicos que ocorrem nos corpos d’água. Segundo Jordão et al. (2007), a mensuração das concentrações de oxigênio dissolvido possibilita avaliar as condições naturais da água, além de detectar impactos ambientais como eutrofização e poluição orgânica.

A média do valor do oxigênio dissolvido (OD) em todos em pontos nas datas de coleta foi $1,99 \pm 0,42 \mathrm{mg} . \mathrm{L}^{-1}$, valor considerado baixo para a sobrevida de peixes. Segundo Von Sperling (2007), os peixes mais exigentes morrem com 0D em torno de 4-5 mg.L $\mathrm{L}^{-1}$. Com OD igual a $2 \mathrm{mg.L}$ , todos os peixes estão mortos e, com 0 mg.. ${ }^{-1}$ de oxigênio, tem-se condições de anaerobiose.

Portanto, os valores medidos neste trabalho justificam não terem sido observados nem mesmo peixes diminutos, de ambientes lênticos e que conseguem viver em águas rasas, poluídas e de baixo teor de oxigênio. Um exemplo de peixes que vivem em tal condição foi registrado no trabalho de Garcia et al. (2015), no córrego Barbado, importante córrego urbano de Cuiabá.

No Gráfico 7 são apresentados os valores de oxigênio dissolvido nos pontos amostrais ao longo das coletas.

Gráfico 7 - Condutividade da água nas datas de coletas nos três pontos amostrais do córrego Engole Cobra, Cuiabá-MT

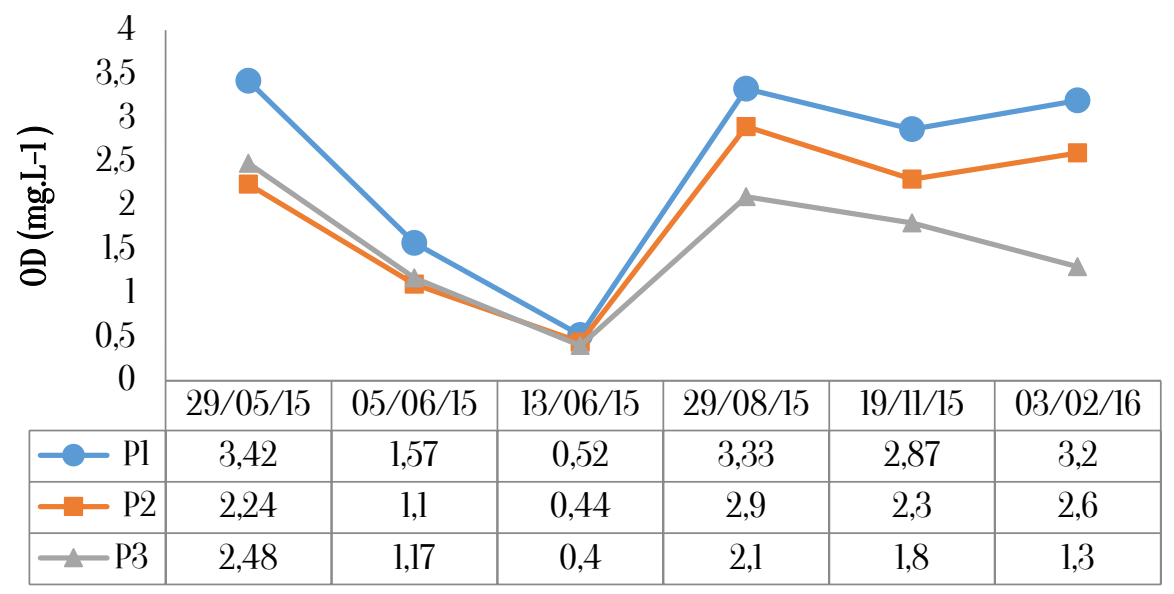

Fonte: Dados coletados in loco pelos autores. 


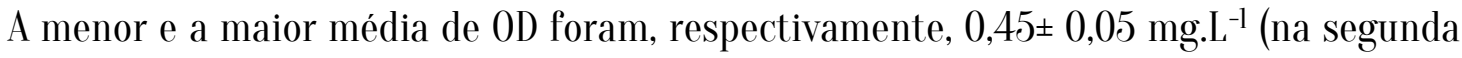

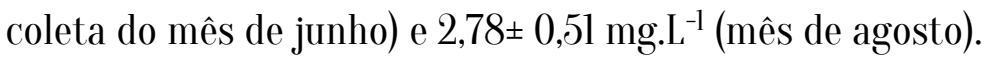

Em meados do mês de junho, onde ocorreram os menores valores, quantidades significativas de matéria orgânica podem ter sido incorporadas ao corpo d'água, o que justificaria em substanciais reduções no OD, com implicações ambientais severas (FIORUCCI e BENEDETTI -FILHO, 2005). Segundo Matos (2001), as bactérias aeróbias, a decomporem a matéria orgânica presente no meio aquático, são as grandes consumidoras do oxigênio dissolvido, o que corrobora a hipóxia do meio. Ainda segundo Fiorucci e Benedetti-Filho (2005), outro indício observado foi a menor média de condutividade comparada às outras datas de coleta.

A diminuição da salinidade aumentaria, em tese, a solubilidade do oxigênio na água, porém observou-se um decréscimo de OD no mês de junho. Segundo Branco (1986), é possível que 0 OD não tenha aumentado, seja pela temperatura da água próximas $30^{\circ} \mathrm{C}$, que favorece a velocidade das reações bioquímicas de degradação de matéria orgânica pelos microrganismos facultativos, ou ainda pelos indícios da faixa de pH já relatada, que indica que no córrego estariam acontecendo a reações anaeróbias, o que já implicaria em hipóxia da água local.

De forma geral, a solubilidade dos gases na água diminui com o aumento da temperatura. Porém, observando o mês de agosto, que possui as características de maior média de temperatura da água e maior condutividade - ou seja, maior quantidade de sais dissolvidos -, ocorreu o registro da maior média de 0D. A exemplo do que aconteceu no córrego Barbado, local muito antropizado e no qual observou-se que a presença de algas contribuiu para um aumento expressivo de 0D, por meio da fotossíntese (GARCIA et al., 2015), também no presente estudo foram registradas em agosto, mês de maior estiagem, plantas aquáticas no meio do lodo. É importante ressaltar que o oxigênio em excesso, produzido pelo processo fotossintético das plantas aquáticas, é liberado para a atmosfera - isto é, não permanece disponível por muito tempo para decompor a matéria orgânica.

Pode-se também notar que, pela pequena extensão de 617,51 m do córrego Engole Cobra e pela carga expressiva de efluentes lançada visivelmente em seu leito, não ocorre autodepuração do ponto 1 para o ponto 3. Pelo contrário, o nível de 0D diminui a cada ponto e, desta forma, quando o esse córrego desagua no córrego Mané Pinto, já leva uma grande carga orgânica, que posteriormente será lançada no rio Cuiabá. 


\section{CONCLUSÃO}

Os moradores não reconhecem no córrego Engole Cobra o córrego de outrora, cujas águas serviram para abastecimento de suas casas, lazer e pesca, representando hoje uma preocupação, devido ao mau cheiro e proliferação de vetores.

Dos parâmetros físico-químicos utilizados para uma avaliação da qualidade de água do córrego Engole Cobra, os que melhores indicaram a elevada degradação, especialmente pelo

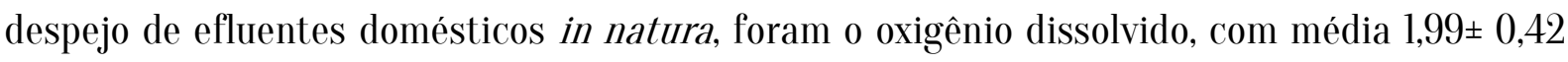

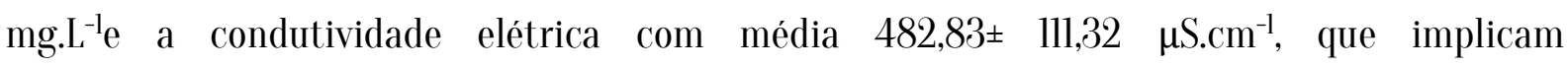
respectivamente num ambiente aquático com hipóxia e predominância de reações anaeróbias e grande quantidade de dejetos dissolvidos na forma iônica, ou seja, um prenuncio da morte do córrego.

Foram observadas grandes quantidades de entulhos, lixos e esgotamentos sanitários ao longo do córrego Engole Cobra, e conclui-se que a realidade desse, assim como de grande número de córregos cuiabanos, encontra-se em situação de descaso por parte da gestão pública do Município de Cuiabá.

Como não há monitoramento da qualidade das águas dos córregos urbanos do município, os resultados desse trabalho poderão servir de subsídio para que o Poder Público invista e faça cumprir a Lei Municipal de Saneamento Básico, em especial a coleta e o tratamento de esgoto domiciliar.

\section{REFERÊNCIAS}

ALBERTI, V. História oral: a experiência do CPDOC. Rio de Janeiro: Centro de Pesquisa e Documentação de História Contemporânea do Brasil, 1989. 202 p.

ALMEIDA, M. M. História Oral e formalidades metodológicas. In: IX Encontro Nacional de História Oral: Memória, democracia e justiça - Anais Eletrônicos. Associação Brasileira de História Oral, 2012. Disponível em: http://www.encontro2012.historiaoral.org.br/resources/anais/3/1332442488_ARQUIV0_ABHOHistoriaoraleformali dadesmetodologicas.pdf. Acesso em: 07/06/2017.

ARAÚJ0, E. C. R. Análise das Áreas de Preservação da Beira de Córregos e Rios do Perímetro Urbano da Cidade de Cuiabá-MT. 2010. 153f. Dissertação de Mestrado. Universidade Federal de Mato Grosso. Departamento de Geografia/Programa de Pós-Graduação em Geografia. 2010.

ARRUDA, G. B.; CORREIA, K. V.; MENOR, E. A.; LINS, V. Contaminações em sulfato e cloretos em águas de superfície e subsuperfície na região de Araripina-PE. Estudos Geológicos, v. 22, n.2, p.149-171, 2012.

ASSOCIAÇÃO BRASILEIRA DE NORMAS TÉCNICAS. NBR 9897: planejamento de amostragem de efluentes líquidos e corpos receptores - procedimento. Rio de Janeiro, 1987. 
Análise físico-química e percepção ambiental do córrego Engole Cobra no município de Cuiabá-MT

ASSOCIAÇÂO BRASILEIRA DE NORMAS TĖCNICAS. NBR 9898: preservação e técnicas de amostragem de efluentes líquidos e corpos receptores - Procedimento. Rio de Janeiro, 1987.

BAPTISTA, M.; NASCIMENTO, N.; BARRAUD, S. Técnicas Compensatórias em Drenagem Urbana. Porto-Alegra: ARBH, 2005. 72 p.

BELIZÁRIO, W.S. Impactos ambientais decorrentes da expansão urbana no córrego Pipa em Aparecida de Goiânia, Goiás. Revista Mirante, v. 7, n. 2, p. 58-77, 2014.

BONI, V.; QUARESMA, S. J. Aprendendo a entrevistar: como fazer entrevistas em Ciências Sociais. Revista Eletrônica dos Pós-Graduandos em Sociologia Política da UFSC, v. 2, n. 1 (3), p. 68-80, 2005.

B0RDEST, S. M. L. A Bacia do Córrego do Barbado, Cuiabá-MT. Cuiabá: Gráfica Print, 2003. 116p.

BRANC0, S.M. Hidrobiología aplicada à engenharia sanitária. 3a ed. São Paulo: CETESB/ASCETESB, 1986. 616p.

BRASIL, Conselho Nacional do Meio Ambiente. Resolução Conama 357/2005. Enquadramento dos Corpos Hídricos Superficiais no Brasil. Governo Federal, Brasilia. Publicada no D0U nº 53, de 18 de março de 2005, Seção 1, p. 58 - 63.

BRITO, R. R.; GOMES, E. R.; LUDWIG, R. USO DA ÁGUA NA IRRIGAÇ̃̃O. Periódico Eletrônico Fórum Ambiental da Alta Paulista, v. 8, n. 2, p.373-383, 2012.

BUZELLI, M. G.; CUNHA SANTINO, M. B. Análise e diagnóstico da qualidade da água e estado trófico do reservatório de Barra Bonita, SP. Revista Ambiente \& Água, v. 8, n. 1, p.186-205, 2013.

CASTR0 JR., P. R.; SALOMÃO, F. X. T.; PAES DE BARROS, L. T. L. MADRUGA, E. L.; GONZAGA, L. N.; CAVALHEIRO, E. S. S. Caracterização e delimitação cartográfica das áreas de preservação permanente (APP’s) e de zonas de interesse ambiental (ZIA's) na área urbana de Cuiabá. Relatório Técnico. Cuiabá-MT: Prefeitura de Cuiabá; IPEM, 2008. 52p.

CETESB - Companhia de Tecnologia de Saneamento Ambiental. Qualidade das águas Interiores no Estado de São Paulo - Significado ambiental e sanitário das variáveis de qualidade das águas e dos sedimentos e metodologias analíticas e de amostragem. Série Relatórios, 2009. Disponível em: www.cetesb.sp.gov.br/userfiles/file/agua/aguas.../variaveis.pdf. Acesso em: 16/09/2016.

ESTEVES, F. A. Fundamentos de Limnologia. 2.ed. Rio de Janeiro: Editora Interciência. 1998.602p.

FIORUCCI, A.R.; BENEDETTI -FILH0, E. A importância do oxigênio dissolvido em ecossistemas aquáticos. Química Nova na Escola, n. 22, p. 10-16, 2005.

FRANKLIN, B.; BARRET0, N.; ALENCASTR0, A. (Editores). Almanaque Cuiabá de Cultura Popular, anol, edição 4. 2015. $18 \mathrm{p}$.

GALDINO, Y. S. N.; ANDRADE, L. M. Z. Interações entre a Cidade e Paisagem ao longo da Sub-Bacia do Barbado, Cuiabá - MT. In: IV Encontro Nacional da Anppas, Brasília - DF. 19p. 2008.

GARCIA, R. A. L.; VALENTINI, C. M. A.; FARIA. R. A. P. G. Aspectos ambientais do córrego Barbado em Cuiabá-MT. Enciclopédia Biosfera, v.1, n.22; p.243-263, 2015.

GUIMARÃES, J.R. e NOUR, E. A. A. Tratando nossos esgotos: Processos que imitam a natureza. Cadernos Temáticos de Química Nova na Escola - Química Ambiental. p. 19-30, 2001.

InSTITUTO NACIONAL DE METEOROLOGIA (INMET). Banco de Dados Meteorológicos para Ensino e Pesquisa. Disponível em: http://www.inmet.gov.br/projetos/rede/pesquisa. Acesso em: 24/05/2016.

JORDÃO, C. P.; RIBEIR0, P. R. S.; MATOS, A. T.; FERNANDES, R. B. A. Aquatic contamination of the turvo limpo river basin at the Minas Gerais state, Brazil. Journal of Brazilian Chemistry Society, v. 18, n. 1, p. 116-125, 2007.

KREISCHER, T. C. V.; GONÇALVES, D. M. M.; VALENTINI, C. M. A. Aspectos hidroambientais do Córrego Barbado em Cuiabá-MT. Revista Holos, ano 28, v.l, p. 86-109, 2012. 
LIBOS, M. Modelagem hidrológica quali-quantitativa: estudo de caso da bacia hidrográfica do rio Manso - MT. 2008. 345f. Tese (Doutorado em Engenharia Civil - Recursos Hídricos). COPPE. UFRJ. Rio de Janeiro - Brasil. 2008.

LIMA, V. Análise da qualidade ambiental urbana: o exemplo de 0swaldo Cruz/SP. Geografia em Questão, v.7, n. 2, p.29-46, 2014.

MACEDO, J. A. B. Águas \& Águas. Belo Horizonte, Minas Gerais: CRQ - MG, 2004, p.208, 691 - 721.

MAGALHÃES, L. Z:; WERLE, H. S. Problemas ambientais de uma cidade média de Mato Grosso: 0 caso de Barra do Bugres. Planejamento e Políticas Públicas, n. 33, p.79-101, 2009.

MAITELLI, G. T.; CHILETT0, E. C.; JUNIOR, N. L. de A.; CHILETTO, R. Intensidade da ilha de calor em Cuiabá/MT, na estação chuvosa. In: XIII Congresso Brasileiro de Meteorologia, Anais. Fortaleza/CE: UFCE, 2004.13 p.

MARICAT0, E. As idéias fora do lugar e o lugar fora das idéias: planejamento urbano no Brasil. P. 121-192. In: ARANTES, 0.; MARICAT0, E.; VAINER, C. (Org.). A cidade do pensamento único. Petrópolis: Vozes, 2000.

MARTINS, E. L. Qualidade de Água do Córrego Barbado. In: Oliveira, M. R. A. (0rg.). Caminhando pelo Barbado: 0 córrego e sua gente. Cuiabá: IFMT/Gráfica Print Ind. e Editora LTDA/Fapemat, 2010. p.33-44.

MARTINS JUNIOR, M. Revendo e reciclando a cultura cuiabana. Cuiabá: Editora Janina. 2000. 170 p.

MATHEUS, C. E.; MORAES, A. J. de; TUNDISI, T. M.; TUNDISI, J. G. Manual de Análises Limnológicas. São Carlos: Centro de Recursos Hídricos e Ecologia Aplicada, UPS. 1995. 62p.

MATOS, A. T. Poluição Ambiental e Seus Efeitos. Brasília: ABEAS; Viçosa. DEA/UFV. 2001. 101p.

MEIHY, J.C.S.B. Manual de história oral. São Paulo: Loyola, 2002. 246p.

PINTO, F. W. C. 0s impactos ambientais decorrentes do processo de urbanização e industrialização: 0 caso do Rio Pajeú, Serra Talhada-PE. 2010. Disponível em: http://www.sober.org.br/palestra/15/1148.pdf. Acesso em: 01/10/2016.

PREFEITURA MUNICIPAL DE CUIABÁ. IPDU-Instituto de Pesquisa e Desenvolvimento Urbano. Perfil Socioeconômico de Cuiabá. Volume IV. Cuiabá: Central de Texto, 2009.

PREFEITURA MUNICIPAL DE CUIABÁ. Plano Municipal de Saneamento Básico ano-2011. Disponível em: http://www.cuiaba.mt.gov.br/upload/arquivo/plano_municipal_de_saneamento_vale.pdf. Acesso em: 09/09/2016.

REBOUÇAS, A.; BRAGA, B.; TUNDISI, J. Águas Doces no Brasil: Capital ecológico uso e conservação. 3 ed. São Paulo: Escrituras, 2006. p.145-160.

REIS, A.; R0GALSKI, J. M. (Org.). Novos aspectos na restauração de áreas degradadas. Florianópolis: PetBiologia/UFSC, 2006. 80p.

SALES, J. Dia Mundial do Meio Ambiente: $80 \%$ dos córregos viraram esgotos e crescimento representa mais riscos. A Gazeta, Cuiabá, p.4 e 5B, 5 jun.2009. Disponível em: 〈http://www.gazetadigital.com.br/pdf. Acesso em: 27/06/2015.

SERILO, D. F.; VALENTINI, C. M. A.; FARIA, R. A. P. G. 0 saneamento básico de Cuiabá-MT na memória dos idosos em um bairro histórico da capital. Biodiversidade, v. 13, n. 1, p. 125-140, 2014.

SILVA, F.A.S. ASSISTAT - Software: statistical assistance. Versão 7.7 beta. 2013.

VON SPERLING, M. Estudos e modelagem da qualidade da água de rios. Belo Horizonte: Editora UFMG. 2007. 588p.

ZUIN, V. G.; IORIATTI, M. C. S.; MATHEUS, C. E. 0 Emprego de Parâmetros Físicos e Químicos para a Avaliação da Qualidade de Águas Naturais: Uma Proposta para a Educação Química e Ambiental na Perspectiva CTSA. Química Nova na Escola, v.31, n.l, p. 3-8, 2009.

ZUMACH, R.; Enquadramento de Curso de Água Rio Itajá-Açu e Seus Principais Afluentes em Blumenau. 2003. 124f. Dissertação (Mestrado) - Programa de Pós-Graduação em Engenharia Ambiental. Universidade Federal de Santa Catarina, Florianópolis, 2003. 